VS Publications

Alford Council of International English \& Literature Journal(ACIELJ)

Impact Factor:4.401(SJIF)An International Peer-Reviewed English Journal

www.acielj.com

Vol-3,Issue-2 ,2020

ISSN:2581-6500

\title{
A NEEDS ANALYSIS STUDY FOR ESL STUDENTS AT UNIVERSITY LEVEL IN SRI LANKA
}

\author{
LakminiRadeeshanikaBasnayake \\ Senior Lecturer \\ Department of English Language Teaching \\ Faculty of Social Sciences \& Languages \\ Sabaragamuwa University of Sri Lanka \\ Belihuloya,Sri Lanka
}

\begin{abstract}
This study examines the needs of English language learners concerning a compulsory English language program at a state university in Sri Lanka to look for solutions and amendments concerning the content and presenting materials of the current textbooks being practiced.In this regard, a needs analysis was carried out through a questionnaire survey on a random sample of $1^{\text {st }}$ and $2^{\text {nd }}$ year students who follow the Core English Language (CEL) program conducted by the Department of English language Teaching at Sabaragamuwa University in Sri Lanka. The data were analyzed quantitatively. Data analysis revealed that explicit grammar teaching was seen negatively by a majority of respondents whose interests favor for speaking and listening activities related to real-life situations. Besides, it was revealed that the inductive teaching approach would be the best way to cater to the needs of ESL learners. The study concluded that authentic materials should be included in the content of textbooks used for the CEL program to attract and motivate students towards learning English.
\end{abstract}

Keywords: Needs analysis, ESL Undergraduates, Curriculum development

\section{Introduction}

Despite many efforts and many years in English language teaching at Sabaragamuwa University, a vast number of students prove that they are not competent enough in English both in terms of communication and the results they gain for semester examinations. This is the major problem found in the field of ELT at the university level and also exploring solutions to reduce the high number of failures in English language courses (CEL: Core English Language) has been a challenge to the particular department: Department of English Language Teaching (DELT).DELT at Sabaragamuwa University was established in 2004. It plays a massive role in improving the English language proficiency of undergraduates majoring in various subjects in the whole faculty -Social Sciences \& Languages. The department offers a compulsory course for the English language named Core English Language (CEL) Level I, II, III, IV commencing from the first semester, first academic year continuing up to the second semester, second academic year.

(Page 99) 
VS Publications

Alford Council of International English \& Literature Journal(ACIELJ)

Impact Factor:4.401(SJIF)An International Peer-Reviewed English Journal

www.acielj.com

Vol-3,Issue-2,2020

ISSN:2581-6500

The present curriculum for CEL at DELT is being used as a guide to the basics of the English language with the positive view that undergraduates will master the language at the end of each course unit. However, the poor performance of the majority of students at semester examinations became a matter of concern in this research project to investigate their perceptions concerning the present curriculum along with their needs and topics of interest.

As CEL is a compulsory course, most of the students who have no basic foundation in English find it difficult to get at least a simple pass, so, this leads to the downfall of their whole academic life because English is a basic requirement to get the degree at the end. Even if the students excel very well in their major subjects, like Economics, Sociology, German, Political Science, etc. they will not be able to get the degree without passing CEL in its four levels. As it is an urgent matter to be considered, this research is an attempt to explore solutions and suggestions to lessen this critical situation of students who are unable to score at least 50 marks out of a hundred. Students from diverse backgrounds come to universities with different interests and varying intelligent levels and learning styles. In this regard, identifying the learner's needs and their themes of interests concerning the English language learning process under the CEL program is crucial.

\section{Aims and objectives}

The study aims to find out the needs of ESL (English as a Second Language) learners concerning their compulsory English language program (CEL) at Sabaragamuwauniversity. Their overall satisfaction and perceptions of the efficiency of the materials and content utilized in the prescribed textbooks, their preferred learning methods, the themes, and topics of interest were investigated throughout this aim of the study. The objective is to find ways and means of creating an English language learning environment not only to pass exams but for real-life communication, as language is mainly used for communication. In this respect, some suggestions to consider preparing teaching materials along with amendments of the current textbooks used for the CEL program would be brought forth as a guide to lecturers and instructors at the particular department.

As a staff member of the Department of English Language Teaching, I have realized that teaching materials for the CEL curriculum so far are mostly developed based on the teachers' perceptions, intuitions, as well as subjective personal beliefs without any objective assessments of the learners' situations and needs. Consequently, the teaching materials do not reliably ensure that the course contents are appropriate, effective, practical, and realistic to enable the students to succeed in mastering English. This factor is visible when examining the poor performance of most of the undergraduates in English-related events and also in semester examination results. 
VS Publications

Alford Council of International English \& Literature Journal(ACIELJ)

Impact Factor:4.401(SJIF)An International Peer-Reviewed English Journal

www.acielj.com

Vol-3,Issue-2 ,2020

ISSN:2581-6500

Through the firsthand experience of conducting ESL lectures, I believe that current textbooks practiced in the CEL program should undergo reformations mainly in terms of the content materials to achieve a better outcome of language production. Thus, in this study, the importance of conducting a needs analysis is often highlighted. Though there have been many types of research on needs analyses concerning ELT programs worldwide, English language departments in Sri Lankan context need further work, so this study stresses that the most important factor to be considered in curriculum development is the learners. Any consideration of curriculum development along with syllabus or material design must begin with a needs analysis.

As this study explores the perspectives and perceptions of ESL learners concerning the compulsory English language program (CEL) conducted by the Department of English Language Teaching, the findings will be of great value to be used as a guide to the English lecturers /instructors at the department in terms of preparing teaching materials. This needs analysis will be very much significant as a database for the curriculum development tasks related to Core English Language (CEL) program at Sabaragamuwa University. This study will initiate positive steps towards reforming the current textbooks in terms of all five language domains: speaking, listening, grammar, reading, and writing. The content and the materials should be designed for the textbooks after examining the students' needs and specifying the language course objectives; particularly, the content and materials should meet the requirements of the job market in the outside world. Based on this issue, this study will motivate future research on curriculum development by exploring students' purposes and assessing their needs and interests as well.

\section{Needs Analysis}

In this section, a brief overview of the origins of needs analysis along with its definitions and purposes are taken into account.

Being aware of the needs of the learners influences not only the content of the language course but also what potential can be exploited through such a course. Martinez states that "the idea of focusing on learners' needs originated in the 1970s resulting from the interest in the design of language courses that could satisfy individual and social needs" ${ }^{1}$. Its development evolved in association with the teaching of languages for specific purposes. A needs analysis, as defined by Brown, is "the systematic collection and analysis of all subjective and objective information necessary to define and validate defensible curriculum purposes that satisfy the language learning requirements of students within the context." 2 Richards (2001) mentions that different students have different language needs and what they are taught should be restricted to what they need $^{3}$.

Brown defines that needs analysis is the systematic data collection and examining of all subjective and objective information required to describe and

\footnotetext{
${ }^{1}$ Martínez, 1992

${ }^{2}$ Brown, 1995

${ }^{3}$ Richards 2001
} 
VS Publications

Alford Council of International English \& Literature Journal(ACIELJ)

Impact Factor:4.401(SJIF)An International Peer-Reviewed English Journal

www.acielj.com

Vol-3,Issue-2,2020

ISSN:2581-6500

validate curriculum goals that support the language learning needs of learners within the context of the institutions that affect the learning and teaching situation ${ }^{4}$. Assessment of objective needs involves the evaluation of the students' proficiency in speaking and comprehension of English. Objective needs are the needs that are inferred from the 'factual information' of learners, which include their language proficiency when attending the courses, the perceived language difficulties and their demand of language in real communication situations ${ }^{5}$. Concerning subjective needs, practical information about the students' attitude towards the target language, their expectations, and their level of confidence, the motivation behind learning a particular language program are the key aspects.

Paradowski (2002) considers that the first step of every syllabus design should be needs analysis, i.e. a set of techniques and procedures used for obtaining information about the learners and situations and purposes for which they want to learn the language ${ }^{6}$. According to Graves, "Needs assessment is the systematic and ongoing process of gathering information about students' needs and preferences, interpreting the information, and then making course decisions based on the interpretation to meet the needs"7. Investigating the specific needs of students is very important as it reveals their knowledge level of the target language and their learning difficulties. Hutchinson and Waters (1987) introduced three aspects to be considered when addressing students' needs: what the learner has to know to

${ }^{4}$ Brown, 2006

${ }^{5}$ Brindley, 1989

${ }^{6}$ Paradowski, 2002

${ }^{7}$ Graves, 1996 function successfully in the target language, what the learner already knows and the gaps of knowledge they still need to learn and the adoption of students' learning preferences ${ }^{8}$.

Needs analysis is the base on which curriculum content, teaching materials, and methods are constructed. Needs analysis is vital in designing any language course, whether it is English for Specific Purposes or a compulsory English program like CEL at DELT, Accordingly, the needs analysis which is carried out in this study plays an important role in making suggestions and amendments to be made in the CEL curriculum. It is significant to gather practical information about the students' attitudes towards the target language, their expectations and their level of confidence, the motivation behind following the CEL program, and any preferences as to how they are willing to learn the language.

\section{Methodology}

There are varied approaches to analyze students' needs such as questionnaires, interviews, telephone conversations, and observations. To conduct my needs analysis, I selected the form of the questionnaire as it enabled me to gather information from many students at the same time. The participants for the questionnaire survey were the first and second-year undergraduates who follow the compulsory English language program (CEL) conducted by the Department of English Language Teaching. Questionnaires were distributed to a random sample of 150 students from both $1^{\text {st }}$ and $2^{\text {nd }}$ year batches, however, only 132 questionnaires received filled, so the

${ }^{8}$ Hutchinson and Waters 1987 
VS Publications

Alford Council of International English \& Literature Journal(ACIELJ)

Impact Factor:4.401(SJIF)An International Peer-Reviewed English Journal

www.acielj.com

Vol-3,Issue-2 ,2020

ISSN:2581-6500

sample consists of 132 students including 3

groups from the first year and another 3 groups from the second year. The questionnaires were distributed within CEL lecture hours; students were requested to hand over the filled questionnaires to the CEL lecturer at the end of their lecture. The data collected through the questionnaire were analyzed quantitatively; numerical data of students were analyzed quantitatively to highlight the percentages of students concerning their learning needs and learner difficulties.

\subsection{Description of the needs analysis questionnaire}

In the needs analysis questionnaire for students, the simple language was used, so that the questions were clear and easy for the students to understand. The questionnaire was in the target language. Concerning the scope of the questionnaire, only 6 questions were included as they could provide the most essential information about learner needs to this study. The questions were of two categories: tick-theanswer for multiple-choice questions and open-ended questions. Multiple-choice questions were included to give learners some guidance and the possibility for quick answers; open-ended questions were used to provide space for learners' views/attitudes and creativity. Incorporating two different question types would cater to different learning styles of the students; some learners prefer open-ended questions, whereas others like multiple-choice questions.

The questions deal with six major areas: reasons for learning English, learner difficulties, topics of interests and needs, preferred learning methods, classroom activities, and their attitudes about the present textbooks. More specifically, the first question enquires students' motivation, attitudes, and the reasons for learning English to see to what extent students need English for their real life. Question number 2 enquires about their learning difficulties in the language areas of writing, reading, grammar, speaking, listening, vocabulary spelling, and pronunciation. This question enables gathering information about their current proficient levels and which areas to be more focused on suggesting new teaching materials. This is a multiple-choice question that requires them to tick what areas of language that are: very difficult, somewhat difficult, and not difficult at all. An openended question is also added here to reveal more about learner difficulties to know what areas should be given more attention in revising the present textbooks.

Question number 3 enquires about the topics and themes of interests and needs in learning English. Many options are given for them to tick as many as possible to suggest new content materials to improve the language skills of reading, writing, speaking, and listening. An open-ended question is added for them to name any other topics according to their age preferences and interests. Question number four dealing with preferred learning methods is to find out their preferences regarding classroom activities. Question number five also enquires about their preferred grammar learning methods to revise the instructional methodologies and teaching approaches for English grammar. 
VS Publications

Alford Council of International English \& Literature Journal(ACIELJ)

Impact Factor:4.401(SJIF)An International Peer-Reviewed English Journal

www.acielj.com

Vol-3,Issue-2,2020

ISSN:2581-6500

A specific question about grammar learning in included mainly to view their perceptions of explicit grammar lessons in the current textbooks and to see whether they would prefer the suggested methods of grammar teaching and learning. Question number six enquires students' satisfaction with the present textbooks through a direct Yes or No answer. If they are not satisfied, an open-ended question is given to writing reasons and suggestions for change.

\section{Analysis}

The following section encloses the data analysis of the questionnaire survey carried out with students concerning different aspects of learner needs such as reasons for learning English, preferred learning methods, themes of interests, difficult areas of language domains, and their satisfaction with the current textbooks, etc.

\section{a) Different reasons for learning English}

A variety of reasons for learning English have been given for them to tick as many as possible. All the respondents study English at the university because it is compulsory for the degree program. Out of 132 respondents, only 29 students enjoy learning English. The following table illustrates the percentage of students who have responded to different reasons according to their individual preferences.

Table 1: Reasons for Learning English

\begin{tabular}{|l|l|}
\hline $\begin{array}{l}\text { Reasons for learning } \\
\text { English }\end{array}$ & Percentage \\
\hline I get better marks at school & $73 \%$ \\
\hline $\begin{array}{l}\text { English is compulsory for } \\
\text { the degree program. }\end{array}$ & $100 \%$ \\
\hline $\begin{array}{l}\text { I realize the importance of } \\
\text { English in the world today }\end{array}$ & $74 \%$ \\
\hline I can talk to foreign people & $19 \%$ \\
\hline
\end{tabular}

\begin{tabular}{|l|l|}
\hline in English & \\
\hline I can travel abroad & $23 . \%$ \\
\hline I can surf the internet & $89 \%$ \\
\hline I enjoy learning English & $22 \%$ \\
\hline I will have a good job & $96 . \%$ \\
\hline $\begin{array}{l}\text { I will have many } \\
\text { opportunities in society }\end{array}$ & $42 . \%$ \\
\hline $\begin{array}{l}\text { I can read books, } \\
\text { newspapers, magazines in } \\
\text { English. }\end{array}$ & $\begin{array}{l}\text { I don't know why I am } \\
\text { studying English }\end{array}$ \\
\hline
\end{tabular}

The analysis reveals that almost all the respondents have ticked the reason that English is compulsory for the degree program which counts $100 \%$. In other words, if English is not compulsory, there might be many students who would drop this subject. Only a very few numbers of students enjoy learning English; that is $22 \%$ of the total respondents. This low percentage draws our attention as to why they cannot enjoy learning English. Only about $74 \%$ of students realize the importance of learning English and about 96\% have the reason to learn English is to find a good job. Surfing the internet is also a considerable reason that a higher percentage of students ticked (96\%). However, students' motivation for reading seems to be very much less that only about $14 \%$ say they learn English to read books and newspapers, etc.

The following chart further illustrates these facts. The analysis reveals that according to the high percentage of students, the two major reasons for learning English are that English is compulsory for the degree program and they can find a good job.

(Page 104) 
VS Publications

Alford Council of International English \& Literature Journal(ACIELJ)

Impact Factor:4.401(SJIF)An International Peer-Reviewed English Journal

www.acielj.com

Vol-3,Issue-2 ,2020

ISSN:2581-6500

Chart 01

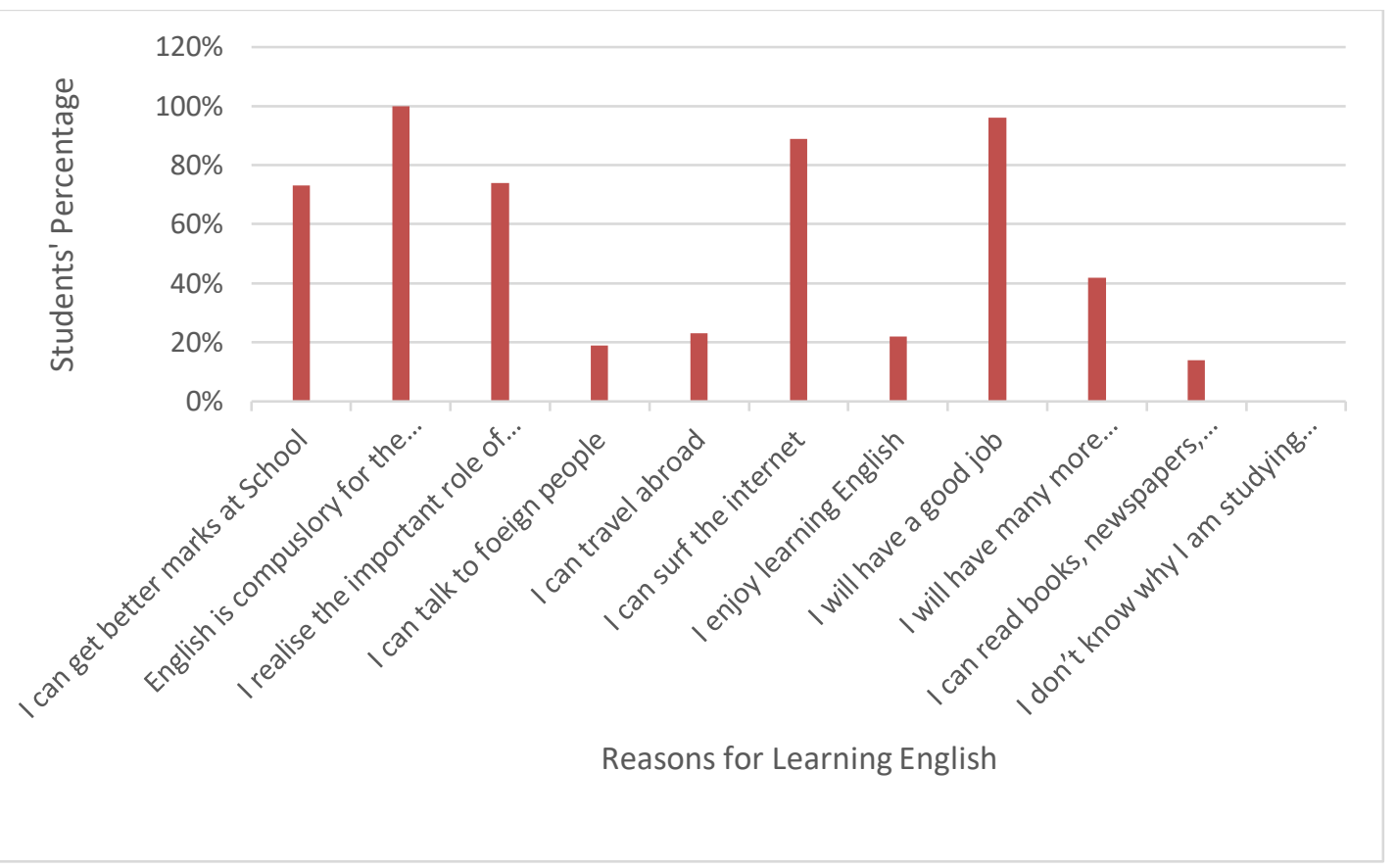

\section{b) Difficult areas of language skills}

Students' learning needs have been given priority in the questionnaire to recognize what areas should be more focused on curriculum development. In this regard, there was a question on what areas of the language that they find difficult in their learning process. 116 students indicated that they find all the domains of language very difficult. About Table 2: Students' percentages regarding difficult language areas

\begin{tabular}{|l|l|l|l|}
\hline Language skills & Very difficult & Somewhat difficult & Not at all \\
\hline Writing & $88 \%$ & $7 \%$ & $5 \%$ \\
\hline Reading & $88 \%$ & $7 \%$ & $5 \%$ \\
\hline Grammar & $88 \%$ & $7 \%$ & $5 \%$ \\
\hline Speaking & $88 \%$ & $7 \%$ & $5 \%$ \\
\hline Listening & $88 \%$ & $7 \%$ & $5 \%$ \\
\hline Vocabulary & $88 \%$ & $7 \%$ & $5 \%$ \\
\hline Spelling & $88 \%$ & $7 \%$ & $5 \%$ \\
\hline Pronunciation & $88 \%$ & $7 \%$ & $5 \%$ \\
\hline
\end{tabular}

(Page 105)
9 students find them somewhat difficult. About 7 students disclose that they are very much confident in the language so do not find any aspect of English difficult at all. The following table indicates the percentage of students who find difficulties in writing, reading, grammar, speaking, listening, vocabulary, spelling, and pronunciation. 
VS Publications

Alford Council of International English \& Literature Journal(ACIELJ)

Impact Factor:4.401(SJIF)An International Peer-Reviewed English Journal

www.acielj.com

Vol-3,Issue-2 ,2020

ISSN:2581-6500

About 5\% of the entire student sample indicated their high proficiency in English whereas $88 \%$ of them indicate their poor competence in reading, writing, grammar, speaking, listening, vocabulary, spelling, and pronunciation. There is an open-ended question followed by this to write any other difficulties in detail. But none of the respondents have answered for that. Chart 2 illustrates the percentage of students and their difficult areas of language skills.

Chart 02

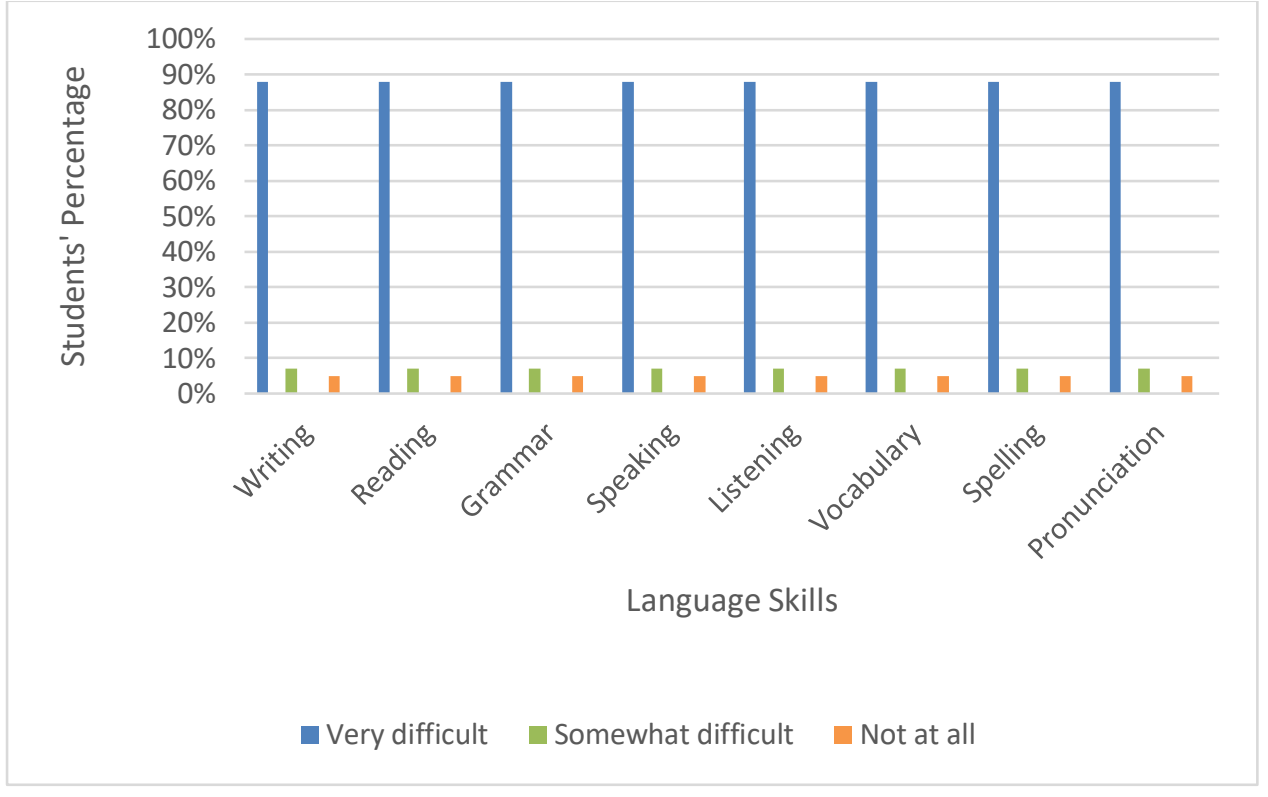

\section{c) Students' responses concerning needs} and themes of interests

The results of the questionnaire analysis reveal the different needs and interests of students in learning English. Data analysis reveals that about 127 respondents have ticked all the topics except technology and the environment. About 5 people have ticked technology and the environment. For the open-ended question to suggest more themes as topics, 102 people have responded with topics like funny stories and fairy tales. Another 30 have suggested topics on writers, newspaper articles, and English news video clips. The following table illustrates the percentages of students concerning the varied needs of topics and interests.

Table 03: Percentages of students concerning themes and topics of interests 
VS Publications

Alford Council of International English \& Literature Journal(ACIELJ)

Impact Factor:4.401(SJIF)An International Peer-Reviewed English Journal www.acielj.com

Vol-3,Issue-2 ,2020

ISSN:2581-6500

\begin{tabular}{|l|l|}
\hline $\begin{array}{l}\text { Topics of } \\
\text { interests/themes }\end{array}$ & $\begin{array}{l}\text { Percentages of } \\
\text { students }\end{array}$ \\
\hline Movies & $96 \%$ \\
\hline Music & $96 \%$ \\
\hline Sports & $96 \%$ \\
\hline Fashion & $96 \%$ \\
\hline Famous people & $96 \%$ \\
\hline Teenagers & $96 \%$ \\
\hline Technology & $4 \%$ \\
\hline Environment & $4 \%$ \\
\hline Art & $96 \%$ \\
\hline Science & $96 \%$ \\
\hline $\begin{array}{l}\text { Funny Stories/Fairy } \\
\text { Tales }\end{array}$ & $77 \%$ \\
\hline News articles/video & $23 \%$ \\
\hline
\end{tabular}

The table indicates that a higher percentage of respondents are interested in topics like movies sports, art fashion, teenagers and famous people. About $77 \%$ have suggested funny stories and fairy tales and only $23 \%$ have declared that they like news articles and videos. There is a lower percentage of students who are interested in technology and the environment. The following chart illustrates the percentage of students their likes and interests.

Chart 03

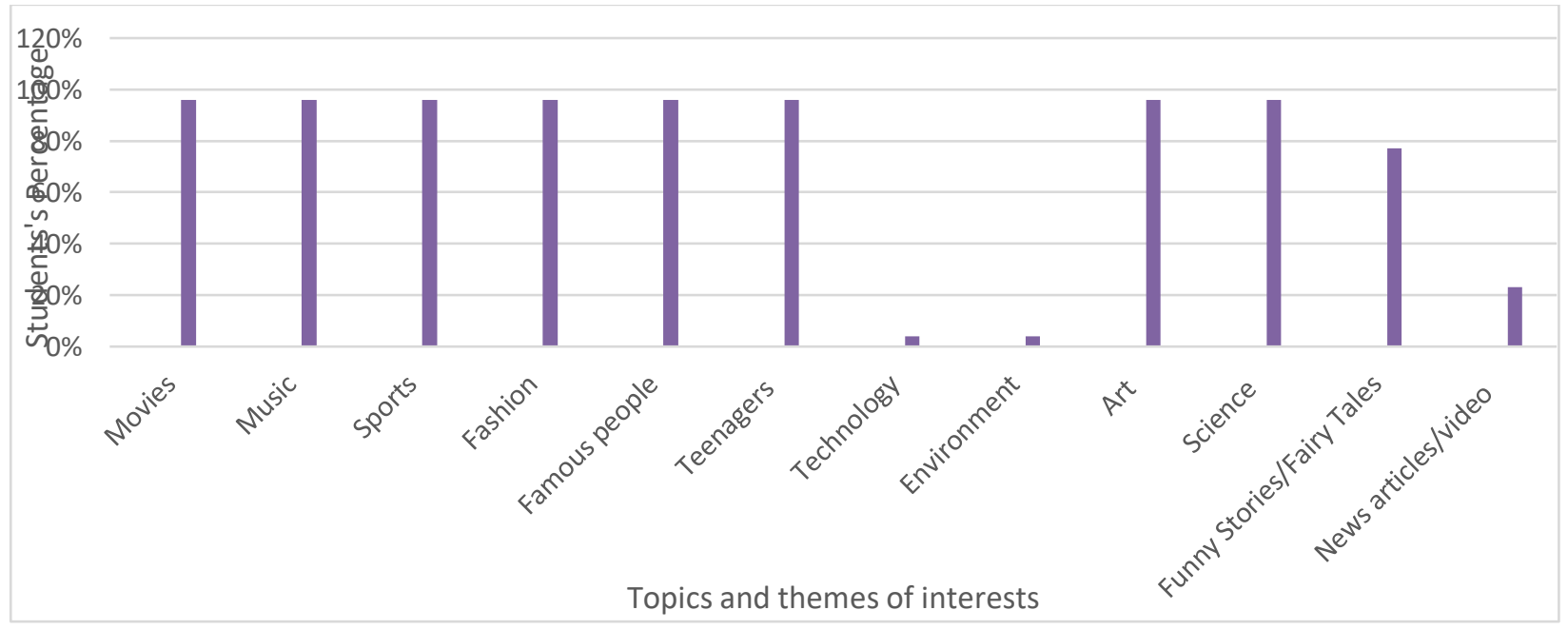

\section{d) Preferred Methods of Learning}

\section{English}

The analysis reveals that working in pairs and groups have been marked by 127 students of the total sample; the same number of students mark only speaking and listening activities as their preferred method of learning English. However, only about 4 students prefer reading quietly and studying on their own. Only 1 respondent marks his/her preferred method of learning English as listening to the teacher. The following table illustrates the percentages of students regarding their preferred methods of learning English. 
VS Publications

Alford Council of International English \& Literature Journal(ACIELJ)

Impact Factor:4.401(SJIF)An International Peer-Reviewed English Journal

www.acielj.com

Vol-3,Issue-2 ,2020

ISSN:2581-6500

Table o4: Percentages of students regarding the preferred methods of learning English

\begin{tabular}{|l|l|}
\hline $\begin{array}{l}\text { Preferred Methods } \\
\text { of Learning } \\
\text { English }\end{array}$ & $\begin{array}{l}\text { Percentages of } \\
\text { Students }\end{array}$ \\
\hline $\begin{array}{l}\text { Like working on } \\
\text { my own }\end{array}$ & $3 \%$ \\
\hline $\begin{array}{l}\text { Like working in } \\
\text { pairs }\end{array}$ & $96 \%$ \\
\hline $\begin{array}{l}\text { Like working in } \\
\text { groups }\end{array}$ & $96 \%$ \\
\hline $\begin{array}{l}\text { Like listening to } \\
\text { the teacher }\end{array}$ & $1 \%$ \\
\hline $\begin{array}{l}\text { Like reading } \\
\text { quietly to learn }\end{array}$ & $3 \%$ \\
English ony & $96 \%$ \\
\hline $\begin{array}{l}\text { Like and } \\
\text { speaking activities }\end{array}$ & $96 \%$ \\
\hline $\begin{array}{l}\text { Like } \\
\text { speaking activities } \\
\text { listening }\end{array}$ \\
\hline $\begin{array}{l}\text { Like only writing } \\
\text { activities } 4 \%\end{array}$ \\
\hline
\end{tabular}

About $96 \%$ of respondents indicate very positive views on working in pairs and groups. A higher percentage of students (96\%) like to engage in many speaking activities which reveal the fact they do not have many opportunities to speak communicatively in the classroom. An important fact these data reveal is that the results of the questionnaire indicate a very low percentage of students who like to work on their own through self-studies. That is $3 \%$ of the entire sample. About $1 \%$ of the entire sample likes to listen to the teacher to learn English depending on the teacher. About 3\% of the sample like to read quietly to learn English. Besides, about $96 \%$ of students state that they like only speaking and listening activities. About 4\% mentioned that they like only writing activities. The following chart further illustrates the varying percentages.

Chart 4

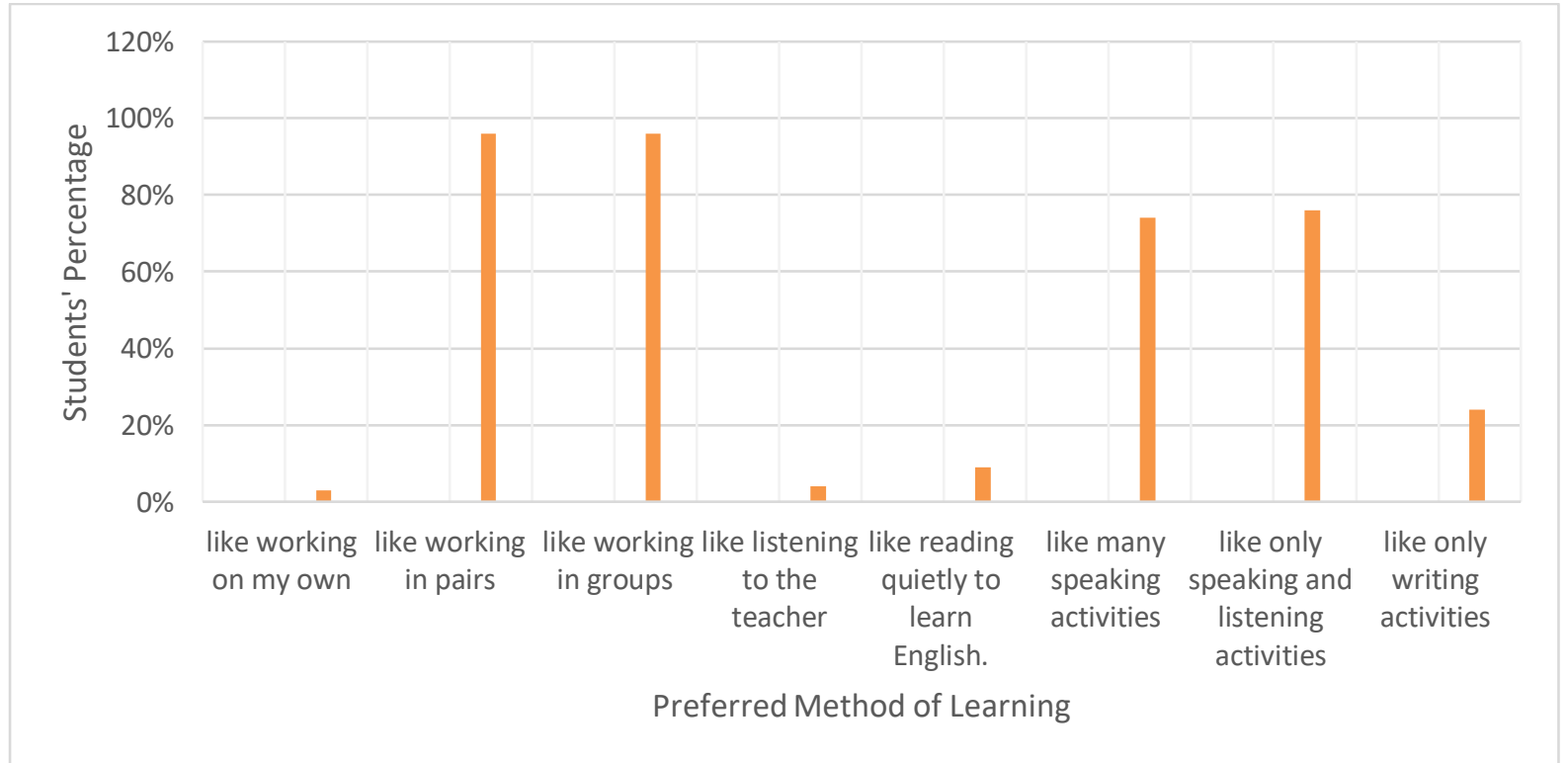

(Page 108) 
VS Publications

Alford Council of International English \& Literature Journal(ACIELJ)

Impact Factor:4.401(SJIF)An International Peer-Reviewed English Journal

www.acielj.com

Vol-3,Issue-2,2020

ISSN:2581-6500

\section{e) Preferred Methods of Learning}

\section{Grammar}

Most students do not like grammar and they get low grades for the semester exam paper which is highly grammar-oriented. Studying grammatical rules explained by the teacher is rejected by 121 respondents which indicates their dislike towards the traditional way of learning grammar. About 119 respondents have disagreed with teaching grammar through power- point presentations of the teacher. The majority of students indicate positive views on listening to authentic materials through you-tube videos, songs, and dramas. Peer teaching is also a positive attitude among 91 students of the sample. So, through this questionnaire survey, the following percentages of students mark their preferences concerning different learning methods of learning English grammar.

Table 05: Students' percentages concerning the preferred method of learning English.

\begin{tabular}{|l|l|l|l|}
\hline Methods of Learning Grammar & Disagree & $\begin{array}{l}\text { Agree to some } \\
\text { extent }\end{array}$ & Agree \\
\hline $\begin{array}{l}\text { Studying grammatical rules explained by the } \\
\text { teacher }\end{array}$ & $92 \%$ & $8 \%$ & $0 \%$ \\
\hline Doing more exercises at home & $65 \%$ & $11 \%$ & $24 \%$ \\
\hline $\begin{array}{l}\text { Listening to authentic materials (YouTube } \\
\text { videos, songs, dramas) }\end{array}$ & $8 \%$ & $11 \%$ & $81 \%$ \\
\hline $\begin{array}{l}\text { Viewing PowerPoint presentations of the } \\
\text { teacher }\end{array}$ & $90 \%$ & $5 \%$ & $5 \%$ \\
\hline Peer teaching (students teach themselves) & $17 \%$ & $14 \%$ & $69 \%$ \\
\hline
\end{tabular}

Considering the percentages of students concerning their preferred methods of learning grammar, about $81 \%$ of the sample are in favor of learning grammar through listening to authentic materials; about $92 \%$ of the sample disagreed with the explicit instruction of grammar rules which is the going method of learning grammar under CEL program. The following chart furthermore illustrates the preferred learning methods of grammar:

Chart 05

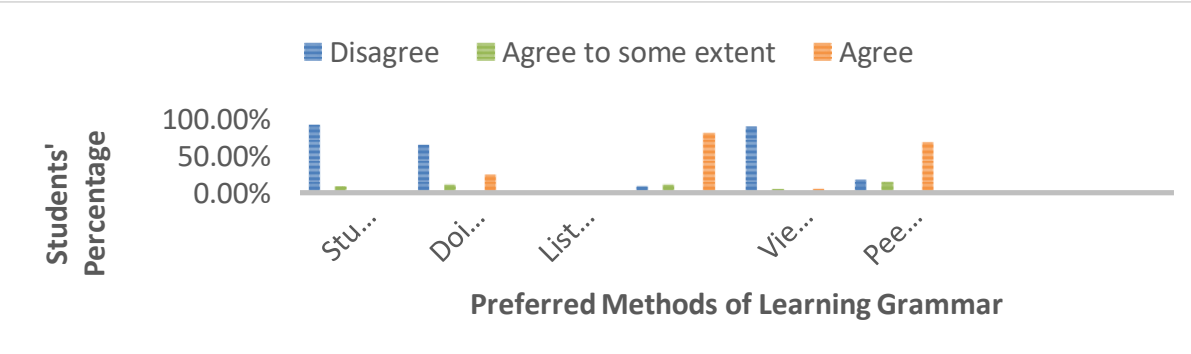

(Page 109) 
VS Publications

Alford Council of International English \& Literature Journal(ACIELJ)

Impact Factor:4.401(SJIF)An International Peer-Reviewed English Journal

www.acielj.com

Vol-3,Issue-2 ,2020

ISSN:2581-6500

\section{f) Students' viewpoints using the current textbooks}

Their overall satisfaction with using the present textbooks has been enquired with a Yes-No question as well as an open-ended question. Adding an open-ended question is very important to get to know the reasons as to why they do not like the textbooks which enable us to recognize what areas should be revised in the present textbooks in curriculum development.

About 93 students indicated their dissatisfaction with the current textbooks and they give reasons as the textbooks are very much grammar-based, so they don't get any kind of motivation to learn English. They have explained in detail that the textbooks include too many lessons on grammar and some grammar lessons are very descriptive that they don't like to read grammar rules. Taped scripts and songs used for the listening activities are not Chart 06 interesting enough and very much outdated, they mentioned. About 39 students indicate their contentment of the textbooks being practiced at present. The following table illustrates the huge gap between those who like the current textbooks and those who do not like it.

Table 06: Students' overall perception of the current textbooks

\begin{tabular}{|l|l|l|}
\hline Opinion & Yes & No \\
\hline $\begin{array}{l}\text { Are you } \\
\text { happy with } \\
\text { the } \\
\text { textbooks? }\end{array}$ & & $70 \%$ \\
\hline
\end{tabular}

About $30 \%$ of student respondents are satisfied with the current textbooks whereas $70 \%$ of respondents are not happy with them. Chart 06 further illustrates their perspectives on the current textbooks.

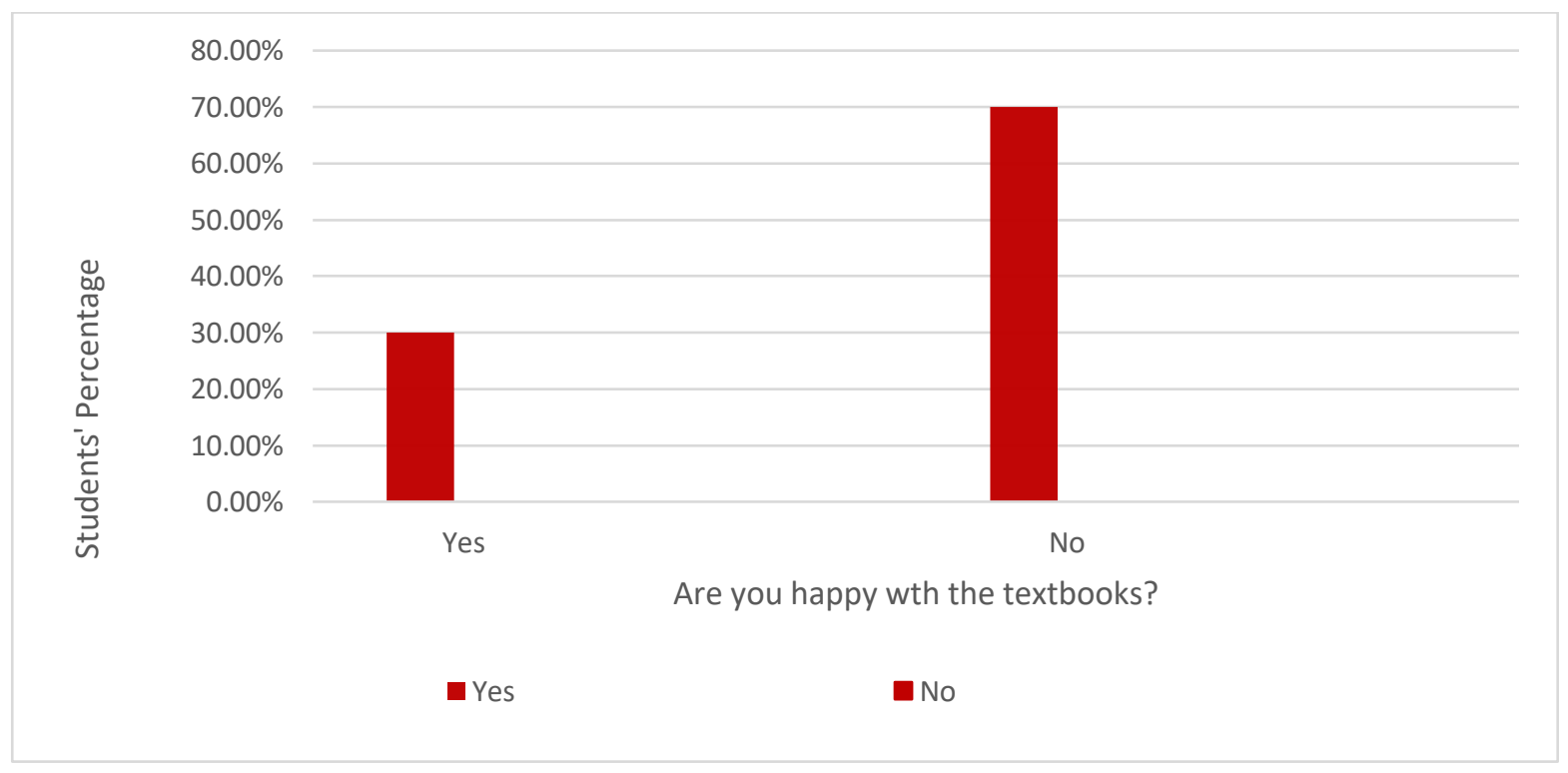

(Page 110) 
VS Publications

Alford Council of International English \& Literature Journal(ACIELJ)

Impact Factor:4.401(SJIF)An International Peer-Reviewed English Journal

www.acielj.com

Vol-3,Issue-2,2020

ISSN:2581-6500

\section{Results}

The analysis of the questionnaire based on students' needs, interests, and deficiencies in the English language learning process reveals several important factors to be considered in revising the content and materials of the textbooks used for the CEL program. Concomitant to what Hutchinson and Waters (1987) state concerning important aspects to be considered in addressing the needs of students, this needs analysis was carried out concerning the students' current proficiency level, learner difficulties in language skills, and their preferences to identify the gap in terms of teachinglearning process of English language under CEL program. About $88 \%$ of respondents of the student sample state they find all the domains of language very difficult. It reveals that the CEL program should cater to the needs of very weak students in general; there should be special attention in revising the content and the materials for reading, writing, grammar, speaking, listening, and vocabulary. There should be new materials presented for pronunciation tasks. So, the textbooks should be revised to attract these weak students for the subject CEL. Recognizing their weaknesses, the next task is to discover their needs and interests. Importantly, their topics and themes of interest have been identified to select the content materials for reading, writing, grammar, speaking, and also listening. The most wanted areas of interest in students have been recognized as movies, music, sports, fashion, famous people, teenagers, fairy tales, comic stories, newspapers, and video clips on English news. As a staff member who conducts English language lectures under the CEL program, the importance of discovering students' needs has been identified as there is a huge gap between what they learn at present and what they want in their English language learning process.

The results of the questionnaire survey revealed that there is a lower percentage of students (22\%) who enjoy learning English. This low percentage draws our attention as to why the other $78 \%$ of the respondents cannot enjoy learning English. Though exam results are important, students should be distracted from the exam-oriented mentality that there should be an interesting curriculum to make English a loved subject even among weak students; there should be ways and means of making the students enjoy learning the subject. About $96 \%$ of respondents tick their reason to learn English as finding a good job. So, the content and materials of CEL should be modified to suit the job market as well. Concerning the preferred methods of learning, a higher percentage of respondents $(96 \%)$ state that they like pair work/group work in learning the English language in the classroom. About 96\% are interested in only in speaking and listening activities. The content and materials in the current textbooks do not correspond to these communicative needs of students. Designing communicative tasks to make them engage in group activities and pair work is identified as an essential aspect in revising the textbooks. The analysis of the questionnaire results reveals yet another important aspect to be considered in curriculum revision.

(Page 111) 
VS Publications

Alford Council of International English \& Literature Journal(ACIELJ)

Impact Factor:4.401(SJIF)An International Peer-Reviewed English Journal

www.acielj.com

Vol-3,Issue-2,2020

ISSN:2581-6500

Only $3 \%$ of the sample likes to study on their own, so this reveals the nature of students and their attitudes as well. This is strong evidence of the extent to which they believe that attending lectures solely helps to improve their language skills. This factor voices the need of encouraging students to do self-learning activities like fast reading and quiet reading of simple stories, scanning, and skimming of newspaper articles, so creating homebased tasks, worksheets and free writing activities would be a timely need in this regard.

The preferred method of learning grammar has been enquired in the student questionnaire. The majority of respondents state positively about learning grammar implicitly rather than explicitly talking about grammar rules. A higher percentage of respondents had positive views on using authentic materials to learn grammar such as songs, stories, cartoons, and video clips on real-life situations; and some have suggested English news video clips as well. In language learning, the most required skill is speaking. It is high time now to switch to authentic material preparation to teach grammar as they can learn not only grammar rules but how to use appropriate language for different situations in real life. The integration of authentic materials to teach the English language is a plus factor identified by this needs analysis. Nunan and Miller (1995) define authentic materials as those which were not created or edited for use in the language classroom, but as those which are kept intact with no interference as they are presented to native speakers with no modification whatsoever to suit the needs of the language learners. They are used to imply the language produced by a real speaker/writer for a real audience, conveying a real message 9 . I have noticed that most textbooks used in language teaching programs in Sri Lanka are very much grammar oriented, students learn grammar in isolation, so they find it very difficult to apply grammar rules in real-life communication. Thus, designing content materials should be carefully structured with students' themes of interests related to real-life situations, so with their familiar situations, they tend to learn English in a stress-free environment.

\section{Conclusion with Recommendations}

The results of the needs analysis questionnaire indicate the weaknesses and deficiencies of the CEL program and the type of needs and interests of the target group that should be focused on revising and amending the content and materials of the current CEL curriculum. The analysis of the questionnaire results reveals that a higher percentage of students are very weak in reading, writing, and grammar and speaking. It is an important fact to recognize that students try to pass the exam by merely studying made-up English, but they fail the exams as they don't know how to incorporate even their limited English knowledge in writing answers with appropriate language use. Furthermore, they fail to communicate in English outside the classroom. This reality is further proved by the needs analysis conducted as the majority of respondents are interested in what they do not find in the existing CEL curriculum; they prefer

${ }^{9}$ Nunan and Miller,1995 
VS Publications

Alford Council of International English \& Literature Journal(ACIELJ)

Impact Factor:4.401(SJIF)An International Peer-Reviewed English Journal

www.acielj.com

Vol-3,Issue-2,2020

ISSN:2581-6500

authentic materials that count real-life communication in English. It has been clearly understood from the analysis of this questionnaire that the overall perception of the participants as to the efficiency of the CEL program is inadequate which encloses the fact that learner needs have not been considered in designing the current textbooks, thus, the importance of curriculum revision is highlighted throughout the process of needs analysis in this study.

Based on the results of the needs analysis, some useful suggestions have been brought forth as an effort to improve English learning outcomes at the university level. Creating a stress-free environment in the ESL classroom is identified as a timely need concerning English language programs at Sri Lankan universities. Replacing the traditional model of the teacher-centered classroom by student-friendly ESL classroom is one important suggestion drawn from this needs analysis. Inculcating the inductive teaching approach as opposed to a deductive approach would be a better solution in this regard. In the inductive way of teaching, learners are expected to abstract the rule on their own from the presented material. Both ways of teaching have their advantages and disadvantages. For example, through deductive teaching, grammar rules can be presented clearly and quickly, but this type of teaching might not be equally suited for young and adult learners because young learners may not be able to understand the grammar terminology; adult learners may find it boring and less motivating. Inductive teaching, on the other hand, encourages learners to be more active in the learning process, rather than simply being passive recipients.

It is high time to include speaking and listening activities as many as possible to promote language learning through communication. We learn a language to communicate, so first and foremost, the materials should be designed to enhance speaking skills. Selection of speaking activities should be carefully done to initiate other language-related tasks such as creative writing, story writing, and letter writing; so, there can be effective followup activities at the end of a single speaking activity. In other words, learning English through communication would be the best approach to attract weaker students. Using interactive group work will motivate students to learn English with a team of friends as the majority of the respondents favored group and pair work.

Rather than grammar-oriented textbooks with explicit rules, authentic materials like cartoons, fables, travel guides, real photographs of people and places can be used to teach grammar implicitly; modern songs, interviews with celebrities, extracts of famous movies, and even BBC news clips would be ideal to cater their needs. These modes will motivate students to learn English in proper contexts, so, they learn English for real communication, which eventually helps them pass exams with good grades.

\section{References:}

[1]Brindley, G. 1989. Needs Analysis and Objectives Setting in the Adult Migrant Education Program, George Allen \& Unwin Ltd: Sydney.

(Page 113) 
VS Publications

Alford Council of International English \& Literature Journal(ACIELJ)

Impact Factor:4.401(SJIF)An International Peer-Reviewed English Journal www.acielj.com

ISSN:2581-6500

[2]Brown, H. D. (2001). Teaching

Principles: An Interactive

Approach to

Language Pedagogy. A Pearson

Education Company: New York.

[3]Brown, J. D. (1995). The

Elements of Language Curriculum;

A Systematic Approach to Program

Development. Heinle\&Heinle

Publishers: Boston.

[4]Brown, J.D. (2006) Second language Studies: Curriculum Development. In K. Brown (ed.), Encyclopedia of Language and Linguistics. Elsevier (pp102-110)). Retrieved April 232018 from https://philpapers.org/rec/BROEEO $-2$

[5]Graves, K. (1996). Designing language courses: A guide for teachers. Boston: Heinle\&Heinle.

[6]Hutchinson, T. \& A. Waters. (1987). English for Specific Purposes: A Learning-Centred Approach. Cambridge: Cambridge University Press

[7]Martinez, P. \& Ignacio. An Analysis and Appraisal of the English Language Teaching Situation in Spain from the Perspectives of Teachers and Learners. Ph.D dissertation. Universidade de Santiago de Compostela, 1992: 133-150. Retrieved April 182018 from https://minerva.usc.es/xmlui/handle /10347/13862
[8]Mukundan, J., Hajimohammadi, R., \&Nimehchisalem, V. (2011). Developing an English language textbook evaluation checklist. Contemporary Issues in Education Research, 4(6), 21-28.

[9]Munby, J. (1978).

Communicative syllabus design. Cambridge: Cambridge University Press

[10]Nation, I.S. P., \& Macalister, J. (2010). Language course design. London: Routledge.

[11]Nunan, D. (1992). Research Methods in Language Teaching. Cambridge: Cambridge University Press.

[12]Nunan, D., \& L. Miller, Eds. (1995). New Ways in Teaching Listening. Alexandria, VA: Teachers of English to Speakers of other Languages. Washington DC: TESOL.

[13]Paradowski, M. B. (2002). Needs Analysis as The First Step in Syllabus Design, (online), Retrieved March 03, 2018 from (http://publikacje.ils.uw.edu.pl/pub lication/view)

[14]Porter, D.and J. Roberts.(1981). Authentic listening activities.ELT Journal 36(1):37-47. 